\title{
SYNTHESIS OF Pd/SILICA-ALUMINA MESOPOROUS CATALYST BY USING CATFISH GELATIN AS TEMPLATE FOR HYDROTREATMENT OF PYROLYZED $\alpha$-CELLULOSE
}

\author{
Wiharti $^{1}$, W. Trisunaryanti ${ }^{1, *}$, Triyono ${ }^{1}$, and M. F. Marsuki ${ }^{2}$ \\ ${ }^{1}$ Department of Chemistry, Faculty of Mathematics and Natural Sciences, Universitas Gadjah \\ Mada, Yogyakarta 55281, Indonesia \\ ${ }^{2}$ Department of Sciences Education, Faculty Mathematics and Natural Sciences, Universitas \\ Negeri Malang, Malang 65145, Indonesia \\ *E-mail: wegats@ugm.ac.id
}

\begin{abstract}
Synthesis of Pd catalyst supported by mesoporous silica-alumina (MSA) from Sidoarjo mud with gelatin template from catfish bone for hydrotreatment of pyrolyzed $\alpha$-cellulose had been carried out. The MSA was synthesized using hydrothermal method. The MSA was characterized by FTIR, SAA, XRD, AAS, TEM, and acidity test. The MSA synthesized in this work was impregnated with Pd metal using a wet impregnation method to produce $\mathrm{Pd}(\mathrm{A}) / \mathrm{MSA}(0.004 \mathrm{~g}$ Pd on $0.5 \mathrm{~g}$ MSA) and Pd(B)/MSA (0.008 g Pd on $0.5 \mathrm{~g} \mathrm{MSA})$ catalysts. The catalytic activity of $\mathrm{Pd}(\mathrm{A}) / \mathrm{MSA}$ and $\mathrm{Pd}(\mathrm{B}) / \mathrm{MSA}$ catalysts were evaluated in hydrotreatment of pyrolyzed $\alpha$-cellulose. The MSA presented $\mathrm{Si} / \mathrm{Al}$ ratio, acidity value, BET specific surface area, pore-volume, and BJH desorption pore diameter of $76.55 ; 6.52 \mathrm{mmol} / \mathrm{g} ; 602.61 \mathrm{~m}^{2} / \mathrm{g} ; 0.81 \mathrm{~cm}^{3} / \mathrm{g}$ and $3.60 \mathrm{~nm}$, respectively. $\mathrm{Pd}(\mathrm{B}) / \mathrm{MSA}$ catalyst has Pd metal content of $0.83 \mathrm{wt} . \%$ and acidity value of $15.66 \mathrm{mmol} / \mathrm{g}$ shows the highest catalytic activity in producing a liquid product of 89.01 wt. \% with the main product in the form of acetic acid compounds.
\end{abstract}

Keywords: Hydrotreatment, Silica, Alumina, Pd/MSA, Pyrolysis, Catalysts

(C) RASĀYAN. All rights reserved

\section{INTRODUCTION}

Lignocellulose biomass is a complex matrix with three main components, namely cellulose (40-60\%), hemicellulose (15-30\%) and lignin (10-25\%). ${ }^{1}$ Cellulose is a carbon source that has a high abundance in nature and has great potential to be used as an alternative raw material for the production of bio-based valuable platform molecules. ${ }^{2}$ Lignocellulose biomass is a renewable energy source that can reduce greenhouse gas emissions and environmental pollution. ${ }^{3}$

Pyrolysis is an integrated process for the production of liquid fuels that can be used directly and as a pretreatment step to convert biomass into liquids that have a higher energy content for further processing such as heat, power, biofuel, and chemistry. ${ }^{4}$ Pyrolysis is the heating of organic matter, such as lignocellulose biomass, at high temperatures without oxygen. ${ }^{5}$ The product of biomass pyrolysis consists of liquid products (bio-oil, tar, and water), solid or carbon products and gas mixtures. Bio-oil mostly contains 50-65 wt.\% organic substances, include aldehydes, acids, furans, ketones, guaiacols, phenolics, sugars and syringols; $15-30 \mathrm{wt} . \%$ steam; and $20 \mathrm{wt} . \%$ colloidal compounds. ${ }^{4,6}$

The oxygen content contained in bio-oil can cause undesirable characteristics such as low instability, energy density, corrosion and high viscosity. ${ }^{6}$ Therefore, dismissing excessive oxygen atoms is necessary for increasing bio-oil. To increase the bio-oil product from pyrolysis to diesel fuel, bio-oil requires additional hydrotreatment. Hydrotreatment is an effective way to improve the quality of bio-oil to remove oxygen at $400-773 \mathrm{~K}$ and high $\mathrm{H}_{2}$ partial pressure. ${ }^{6}$ Bio-oil can be one of the renewable alternative energy sources that can provide valuable chemicals and liquid fuels in the future.

The choice of catalyst is one of the important parameters in the process of bio-oil hydrotreatment. Palladium $(\mathrm{Pd})$ precious metals can be used as catalysts in the hydrocracking process. ${ }^{7}$ However, the use

Rasayan J. Chem., 13(2), 1104-1111(2020)

http://dx.doi.org/10.31788/RJC.2020.1325630

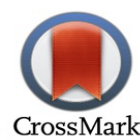


of pure metal immediately as a catalyst is easy to undergo agglomeration and sintering. Therefore, the catalyst needs a support material that has a large amount of surface area to make the contact area between the active site of the catalyst and the feed becomes larger. ${ }^{8}$

Mesoporous silica-alumina (MSA), has been usually used as a catalyst support material, which is synthesized from silica and alumina extracted from Sidoarjo mud using gelatin bone catfish as a template. ${ }^{9-12}$ Gelatin is a promising polymer utilized as a template for synthesis of mesoporous silica because it has a functional group $\mathrm{N}-\mathrm{H}$ which interacts strongly with xylanol $(\mathrm{Si}-\mathrm{OH})$ groups in silicate species through multiple hydrogen bonds. MSA is widely studied because of the presence of acidic sites in $\mathrm{Al}$ at its structure, has optimal pore size, and large surface area. ${ }^{9,10,13,14}$ Silica-alumina is known to be very effective for hydrocracking reactions because it has significant acidity ${ }^{15}$. Pd/silica-alumina catalysts are reported to have high catalytic hydrogenation stability. ${ }^{16} \mathrm{Pd} /$ silica-alumina catalysts are known to be useful in many hydrotreatment processes such as hydrogenation, dehydrogenation and hydrocracking process. ${ }^{16}$

\section{Materials}

\section{EXPERIMENTAL}

Catfish bone obtained from the Tegalrejo Village, Boyolali Regency, Central Java, Indonesia. Sidoarjo mud taken from Sidoarjo Regency, East Java, Indonesia. $\alpha$-cellulose was purchased from Sigma-Aldrich. Palladium chloride, natrium hydroxide, acetic acid and pyridine were purchased from Merck. Hydrochloric acid was purchased from Mallinckrodt.

\section{Synthesis of MSA}

Catfish bone soaked in a base solvent $(0.1 \mathrm{M} \mathrm{NaOH})$ for a day (24 hours) then soaked with acid solvent (1 $\mathrm{M} \mathrm{HCl}$ ) for 1 hour. Gelatin was taken out from the bone of the catfish using aquabidest at $70{ }^{\circ} \mathrm{C}$ for 5 hours. Silica $\left(\mathrm{SiO}_{2}\right)$ and alumina $\left(\mathrm{Al}_{2} \mathrm{O}_{3}\right)$ were taken out from Sidoarjo mud using $6 \mathrm{M} \mathrm{NaOH}$ and $6 \mathrm{M}$ $\mathrm{HCl}$ solutions at $90{ }^{\circ} \mathrm{C}$ for 5 hours. Gelatin was liquified in aquabidest at $40^{\circ} \mathrm{C}$ and stirred for 30 minutes. The gelatin solution was added with $\mathrm{Al}_{2} \mathrm{O}_{3}$ and the mixture was stirred for 30 minutes. In another glass container, the silica was dissolved in aquabidest and stirred for 30 minutes. The silica solution was added with $\mathrm{CH}_{3} \mathrm{COOH} 1 \mathrm{M}$ solution to reach $\mathrm{pH}$. The silica solution was introduced into the gelatin-alumina mixture and the gelatin-alumina-silica mixture was then stirred for 24 hours at room temperature. The formed gel was moved into the autoclave and heated to $100{ }^{\circ} \mathrm{C}$ for 24 hours. The solid obtained from autoclave was filtered and rinsed with aquabidest. The solid was then heated at $50{ }^{\circ} \mathrm{C}$ for 24 hours. The solid was calcined at $550^{\circ} \mathrm{C}$ for 4 hours to remove the gelatin and the produced solid was the MSA. The obtained MSA was characterized by FTIR, XRD, AAS, SAA, TEM and acidity test.

\section{Pd Metal Impregnation on MSA}

$\mathrm{Pd}$ metal is $0.004 \mathrm{~g} \mathrm{Pd}(\mathrm{A})$ and $0.008 \mathrm{~g} \mathrm{Pd}(\mathrm{B})$ is applied to $0.5 \mathrm{~g}$ MSA with a wet impregnation method using $\mathrm{PdCl}_{2}$ solution. The mixture of the $\mathrm{MSA}$ and $\mathrm{PdCl}_{2}$ solution was stirred at room temperature for 24 hours and heated at $70{ }^{\circ} \mathrm{C}$ for 2 hours. The formed catalyst was calcined at $500{ }^{\circ} \mathrm{C}$ under $\mathrm{N}_{2}$ gas stream. The produced catalysts were reduced using $\mathrm{H}_{2}$ gas stream at $450{ }^{\circ} \mathrm{C}$ for 3 hours. The resulting catalyst named $\mathrm{Pd}(\mathrm{A}) / \mathrm{MSA}$ and $\mathrm{Pd}(\mathrm{B}) / \mathrm{MSA}$ were then analyzed by ICP to determine the metal content of the catalysts and acidity test.

\section{Acidity Test}

The MSA and catalysts were acidities tested using the gravimetric method of pyridine adsorption into the sample at room temperature for 24 hours under vacuum condition. The acidity value is calculated based on the weight of the sample before absorption $\left(\mathrm{m}_{1}\right)$ and the weight of the sample after pyridine absorption $\left(\mathrm{m}_{2}\right)$ using the following equation:

\section{Hydrotreatment of Pyrolized $\alpha$-Cellulose}

$$
\text { Acidity Value }=\frac{m_{2}-m_{1}}{m_{1} \times \text { Mr Pyridine }}
$$

$\alpha$-cellulose pyrolysis was carried out at $600{ }^{\circ} \mathrm{C}$ for 3 hours with $\mathrm{N}_{2}$ gas stream to generate the pyrolyzed $\alpha$-cellulose. $\mathbf{z}$ was processed hydrotreatment at $450^{\circ} \mathrm{C}$ for 2 hours in a semi-batch stainless steel reactor 
RASĀYAN J. Chem.

Vol. 13 | No. 2 |1104 - 1111| April - June | 2020

(id: $4.5 \mathrm{~cm}$, od: $4.8 \mathrm{~cm}$, length: $30 \mathrm{~cm}$ ) using the synthesized catalyst. The catalyst to feed ratio is 1:30. Liquid products from hydrotreatment $\alpha$-cellulose were analyzed with GC-MS.

\section{Sample Characterization}

The analysis instruments of gelatin characterization used in this research were the Fourier Transform Infrared/FTIR spectrometer (Shimadzu Prestige-21) fitted with data station in the range from 400 to 4000 $\mathrm{cm}^{-1}$ with a $\mathrm{KBr}$ disc technique. Silica and alumina extracts were characterized using an X-Ray Fluoroscence XRF, PANalytical Type Minipal4) with mining mode analysis. The pore images of the MSA was taken using Transmission Electron Microscope/TEM (JEOL JEM-1400) at $120 \mathrm{kV}$ accelerating voltage. The Atomic Absorption Spectrometer/AAS (PERKIN ELMER 5100) was used to determine Si and Al content of the MSA. X-Ray Diffraction/XRD (Rigaku MiniFlex 600) was used to inspect the crystallinity of the MSA and Surface Area Analyzer/SAA (NOVA 1200e) was used to determine the surface parameters (surface area, pore diameter and pore volume) of the MSA. Analysis of metal content in the catalyst was analyzed using Inductively Coupled Plasma (ICP, Shimadzu ICPE-9820). Liquid products obtained from pyrolysis and hydrotreatment processes $\alpha$-cellulose were analyzed using gas chromatography-mass spectrometer/GC-MS (Shimadzu QP2010S) with helium gas as a carrier gas and an acceleration voltage of $70 \mathrm{Ev}$ with a column diameter of $0.25 \mathrm{~mm}$, the length of $30 \mathrm{~m}$, the thickness of $0.25 \mu \mathrm{m}$ at a temperature of $60-310^{\circ} \mathrm{C}$.

\section{Characterization of Gelatin}

\section{RESULTS AND DISCUSSION}

Catfish bone as the source of gelatin was given base immersion treatment using $0.1 \mathrm{M} \mathrm{NaOH}$ solution for $24 \mathrm{~h}$ and continued immersion of acid with $1.0 \mathrm{M} \mathrm{HCl}$ solution for $1 \mathrm{~h}$. Immersion with $\mathrm{NaOH}$ aims to dissolve non-collagen proteins while immersion with $\mathrm{HCl}$ aims to demineralize catfish bones. Generally, gelatin has five typical amide-adsorbing regions in the FTIR spectra called as amide I, amide II, amide III, amide A, and amide B. The FTIR spectra in Fig.-1 shows extracted gelatin containing five types of typical amide uptake of the gelatin molecule.

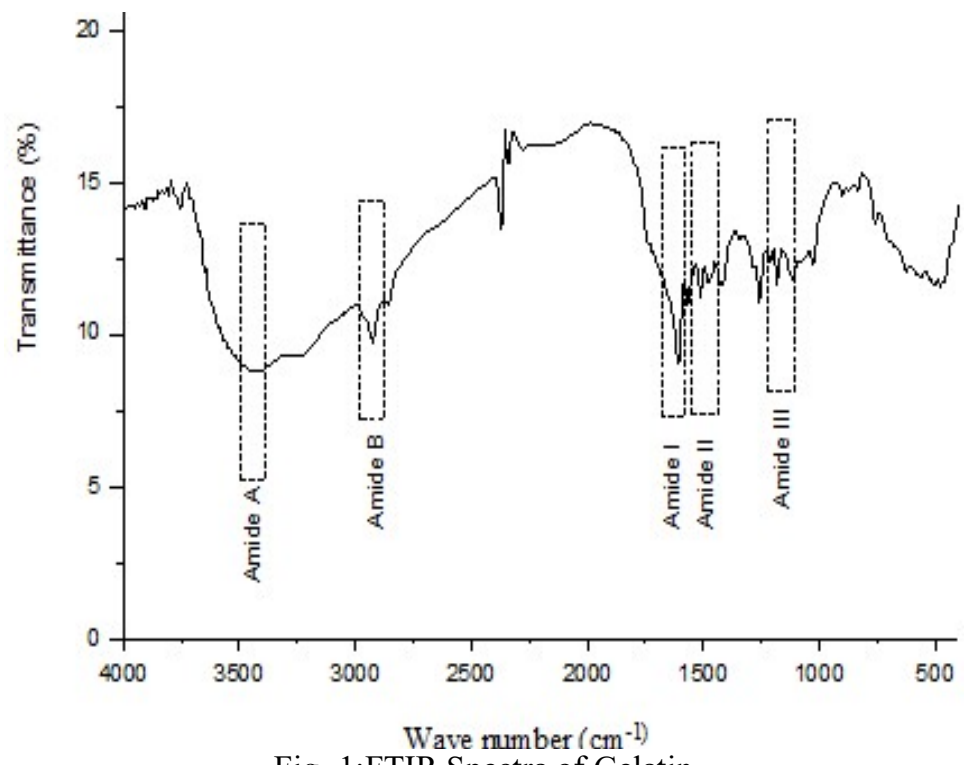

Fig.-1:FTIR Spectra of Gelatin

The amide A uptake occurs at $3425 \mathrm{~cm}^{-1}$ wavenumbers indicating the stretching vibration of the $\mathrm{N}-\mathrm{H}$ and $\mathrm{O}-\mathrm{H}$ groups ${ }^{17,18}$. Amide B occurs at a wavenumber $2924 \mathrm{~cm}^{-1}$ indicating the presence of vibration asymmetry chain $\mathrm{CH}_{2}{ }^{11,19-21}$. Amide I appear on the wavenumber $1604 \mathrm{~cm}^{-1}$ which is the vibration of the $\mathrm{C}=\mathrm{O}$ group ${ }^{17}$. Amide II appears at $1512 \mathrm{~cm}^{-1}$ wavenumbers indicating the bending vibration of the $\mathrm{NH}$ group and the stretching vibration of the $\mathrm{CN}$ group ${ }^{22}$. The observed absorption at $1211 \mathrm{~cm}^{-1}$ wave number 
RASĀYAN J. Chem.

Vol. 13 | No. 2 |1104 - 1111| April - June | 2020

is called an amide III showing the combination peaks between NH deformation from amide linkages, $\mathrm{CN}$ stretching vibrations and $\mathrm{CH}_{2}$ wagging vibrations ${ }^{18}$. The emergence of the amide III uptake shows the loss of the triple structure of the molecular helices due to the denaturation of collagen into gelatin ${ }^{23}$. The yield of gelatin obtained was $6.58 \%$. This gelatin is used as a mold in the synthesis of MSA.

\section{Characterization of Alumina and Silica Extract From Sidoarjo Mud}

The content of alumina and silica from Sidoarjo mud based on XRF analysis (Table-1) is quite high at $11 \%$ and $34 \%$, respectively. It means that the Sidoarjo mud has the potential to be the source of alumina and silica in MSA synthesis. The results showed that the purity of alumina and silica produced from Sidoarjo mud was about $96.10 \%$ and $85.90 \%$, respectively.

\begin{tabular}{c|c|c|c}
\hline \multirow{2}{*}{ Table-1: Composition of Sidoarjo Mud } \\
\hline \multirow{2}{*}{ Metal Oxide } & \multicolumn{3}{|c}{ Content in the Sample (\%) } \\
\cline { 2 - 4 } & Sidoarjo mud & Silika Extract & Alumina Extract \\
\hline $\mathrm{SiO}_{2}$ & 34.00 & 96.10 & - \\
\hline $\mathrm{Al}_{2} \mathrm{O}_{3}$ & 11.00 & - & 85.90 \\
\hline Others & $55.16^{\mathrm{a}}$ & $3.84^{\mathrm{b}}$ & $14.18^{\mathrm{c}}$ \\
\hline
\end{tabular}

\footnotetext{
${ }^{\mathrm{a}} \mathrm{P}, \mathrm{S}, \mathrm{K}, \mathrm{Ca}, \mathrm{Ti}, \mathrm{V}, \mathrm{Cr}, \mathrm{Mn}, \mathrm{Fe}, \mathrm{Ni}, \mathrm{Cu}, \mathrm{Zn}, \mathrm{Br}, \mathrm{Sr}, \mathrm{Eu}, \mathrm{Yb}$, and Re

${ }^{\mathrm{b}} \mathrm{K}, \mathrm{Ca}, \mathrm{Ti}, \mathrm{V}, \mathrm{Fe}$, and $\mathrm{Cu}$

${ }^{\mathrm{c}} \mathrm{P}, \mathrm{Ka}, \mathrm{Ca}, \mathrm{Sc}, \mathrm{Cr}, \mathrm{Fe}, \mathrm{Ni}, \mathrm{Cu}, \mathrm{Zn}, \mathrm{Ga}, \mathrm{In}, \mathrm{Nd}, \mathrm{Yb}, \mathrm{Re}$, and Ir
}

\section{Characterization of MSA}

The MSA characterization using FTIR aims to provide information about the functional groups on the MSA which is presented in Table-2. Table-2 shows the typical absorption produced by the silica-alumina material observed in FTIR spectra. Based on the FTIR spectrum of the MSA, it shows that there is absorption in the area of $3433 \mathrm{~cm}^{-1}$ which shows the presence of $\mathrm{OH}$ stretching vibration bound to $\mathrm{Si}$ or Al. The absorption band at $1635 \mathrm{~cm}^{-1}$ is indicated by water molecules adsorbed in the material. The absorption band at 1095,802 , and $470 \mathrm{~cm}^{-1}$ correspond to the asymmetry and symmetry stretching vibration of T-O and bending vibration of T-O-T, respectively. ${ }^{24}$

Table-2: Interpretation of FTIR SAM Spectra

\begin{tabular}{cc}
\hline Wave Number $\left(\mathrm{cm}^{-1}\right)$ & Type of Vibration \\
\hline 3433 & OH stretching vibration bound to Si or Al \\
\hline 1635 & Bending vibration of the O-H groups \\
\hline 1095 & Asymmetry stretching vibration of T-O \\
\hline 802 & Symmetry stretching vibration of T-O \\
\hline 470 & \\
\hline 600 \\
\hline
\end{tabular}

Fig.-2: Adsorption-desorption Isotherm of MSA 
RASĀYAN J. Chem.

Vol. 13 | No. 2 |1104 - 1111| April - June | 2020

The $\mathrm{N}_{2}$ gas adsorption isotherm graph and $\mathrm{N}_{2}$ gas desorption from the MSA are shown in Fig.-2. The isotherm adsorption and desorption patterns of $\mathrm{N}_{2}$ of MSA gases are included in type IV isotherms based on the IUPAC classification indicating the formation of mesoporous material..$^{11,19-21,25-27}$ The AAS analysis result shows that the $\mathrm{Si} / \mathrm{Al}$ mole ratio in the synthesized MSA is about 76.55 . The acidity value (the amount of pyridine absorbed by the acid site) from MSA is about $6.52 \mathrm{mmol} / \mathrm{g}$. Based on $\mathrm{N}_{2}$ adsorption-desorption analysis result, the MSA has a high surface area $\left(\mathrm{S}_{\mathrm{BET}}\right)$ of $602.61 \mathrm{~m}^{2} / \mathrm{g}$, desorption BJH pore diameter $3.60 \mathrm{~nm}$, and the total pore volume of $0.81 \mathrm{~cm}^{3} / \mathrm{g}$.
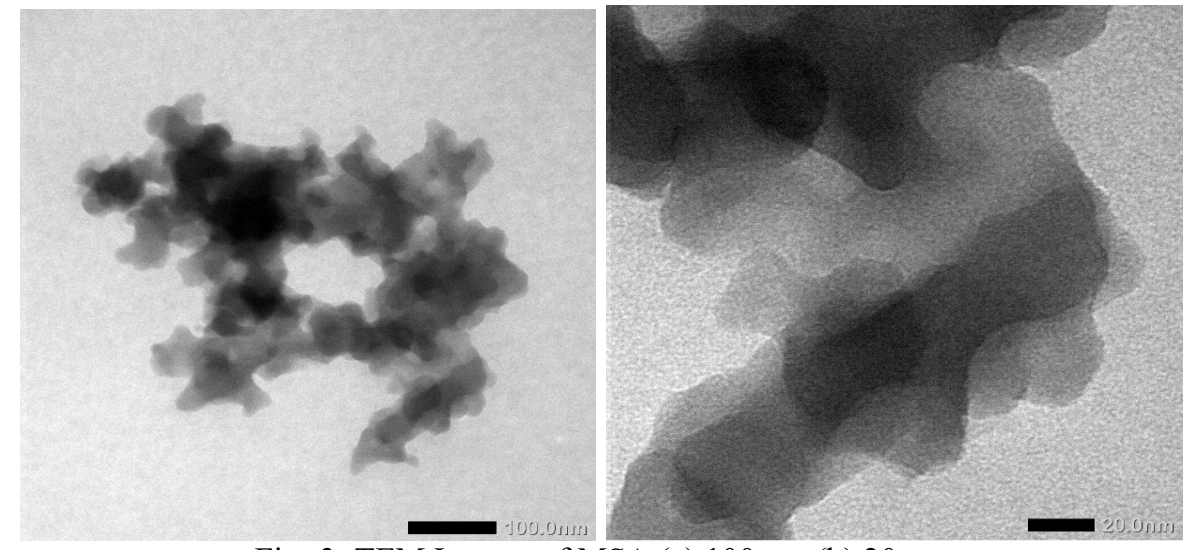

Fig.-3: TEM Images of MSA (a) $100 \mathrm{~nm}$ (b) $20 \mathrm{~nm}$

The morphology of the MSA catalyst was characterized using TEM. TEM image of the MSA (Fig.-3) shows that the MSA has a pore with a structure similar to a wormhole. Wormhole-like structures produced from MSA material synthesized using gelatin molds have also been reported by previous studies. The structure of MSA was analyzed using XRD. Diffractogram of the MSA (Fig.-4) shows that the MSA has an amorphous structure which is characterized by the appearance of a peak that is wide enough at $2 \theta$ around $21^{\circ} .18,20$

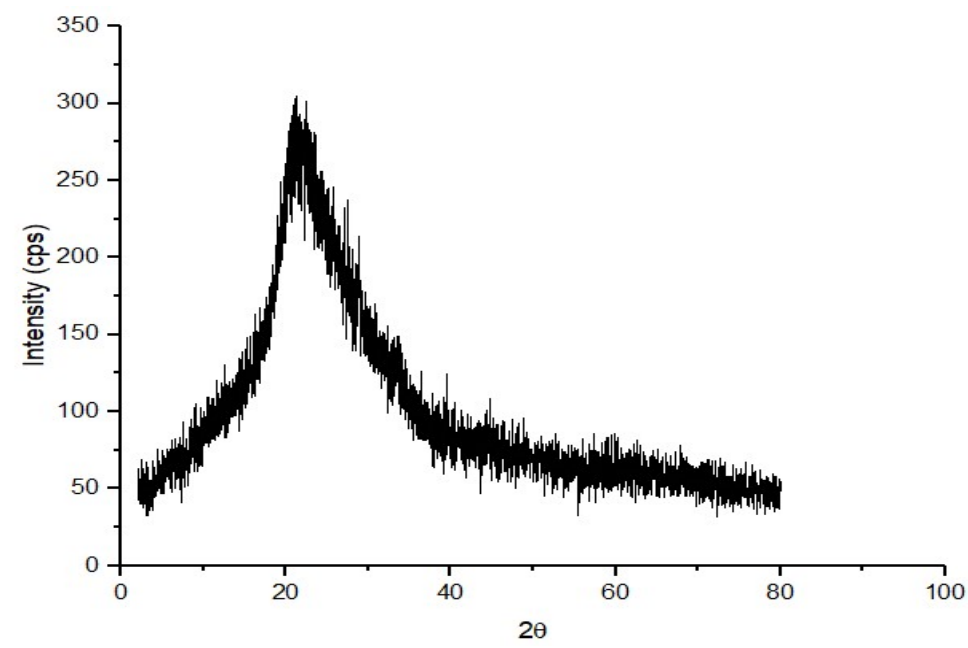

Fig.-4. Diffractogram of the MSA

\section{Characterization of the Catalyst}

The catalysts $\mathrm{Pd}(\mathrm{A}) / \mathrm{MSA}$ and $\mathrm{Pd}(\mathrm{B}) / \mathrm{MSA}$ obtained were investigated using Inductively Coupled PlasmaAtomic Emission Spectroscopy (ICP-AES) and acidity test. The analysis results using those two characterizations indicate that the catalyst $\mathrm{Pd}(\mathrm{A}) / \mathrm{MSA}$ and $\mathrm{Pd}(\mathrm{B}) / \mathrm{MSA}$ have $\mathrm{Pd}$ metal content of 0.44 wt. $\%$ and 0.83 wt. $\%$ as well as acidity value of $14.26 \mathrm{mmol} / \mathrm{g}$ and $15.66 \mathrm{mmol} / \mathrm{g}$, respectively. Based on the data in Table-3, the acidity value of the MSA increases with increasing of Pd levels in the catalyst. $\mathrm{Pd}(\mathrm{B}) /$ MSA catalyst has a higher acidity value than $\mathrm{Pd}(\mathrm{A}) / \mathrm{MSA}$ catalyst. Pd metal provides empty electron orbitals which can be used as Lewis acid sites to absorb pyridine vapour. ${ }^{11}$ This makes the 
RASĀYAN J. Chem.

Vol. 13 | No. 2 |1104 - 1111| April - June | 2020

amount of pyridine absorbed by catalyst $\mathrm{Pd}(\mathrm{B}) / \mathrm{MSA}$ more than catalyst $\mathrm{Pd}(\mathrm{A}) / \mathrm{MSA}$. The high acidity of the catalyst is expected to increase its catalytic activity in the hydrotreatment process of pyrolyzed $\alpha$ cellulose.

Table-3: Acidity Test and ICP Results

\begin{tabular}{c|c|c}
\hline Catalyst & $\begin{array}{c}\text { Pd Metal Content } \\
(\text { wt. } \%)\end{array}$ & $\begin{array}{c}\text { Acidity Value } \\
(\mathrm{mmol} / \mathrm{g})\end{array}$ \\
\hline $\mathrm{MSA}$ & 0,00 & 6,52 \\
\hline $\mathrm{Pd}(\mathrm{A}) / \mathrm{MSA}$ & 0,44 & 14,26 \\
\hline $\mathrm{Pd}(\mathrm{B}) / \mathrm{MSA}$ & 0,83 & 15,66 \\
\hline
\end{tabular}

\section{The Activity of the Catalyst}

Pyrolysis of $\alpha$-cellulose at $600{ }^{\circ} \mathrm{C}$ produced a yellowish, thick, pungent liquid product, and it contains a lot of oxygenate compounds ${ }^{28}$. Pyrolysis carried out in this study managed to convert $\alpha$-cellulose into liquid products by $47.80 \mathrm{wt} . \%$. The five main components of pyrolyzed $\alpha$-cellulose in this study were acetone (11.07 wt.\%), 9-octadecanoic acid (8.21 wt.\%), hexadecanoic acid (5.86 wt.\%), acetic acid (5.45 wt.\%) and 1-hydroxy-2-propanone (3.92 wt.\%). The synthesis catalyst was used for hydrotreatment of bio-oil from the pyrolysis of $\alpha$-cellulose at $450{ }^{\circ} \mathrm{C}$ for 2 hours under $\mathrm{H}_{2}$ gas stream (flow rate of 20 $\mathrm{mL} /$ minute). The catalyst to feed ratio is $1: 30$. For comparison, hydrotreatment process of bio-oil from the pyrolysis of $\alpha$-cellulose was also carried out without using a catalyst (thermal).

Thermal hydrotreatment was carried out to evaluate the activity of the catalysts synthesized in this work in hydrotreatment process of the pyrolyzed $\alpha$-cellulose. The hydrotreatment process of pyrolyzed $\alpha$ cellulose produces three kinds of products which are a liquid fraction, coke, and gas fraction as presented in Fig.-5. Hydrotreatment of pyrolyzed $\alpha$-cellulose using catalysts produced a larger amount of liquid product than the hydrotreatment process without using a catalyst. Hydrotreatment of pyrolyzed $\alpha-$ cellulose generated the highest amount of liquid product using Pd(B)/MSA catalyst (about 89.01 wt.\%). This phenomenon indicates that hydrogenation activity increases with increasing metal content of the catalyst. $^{7}$

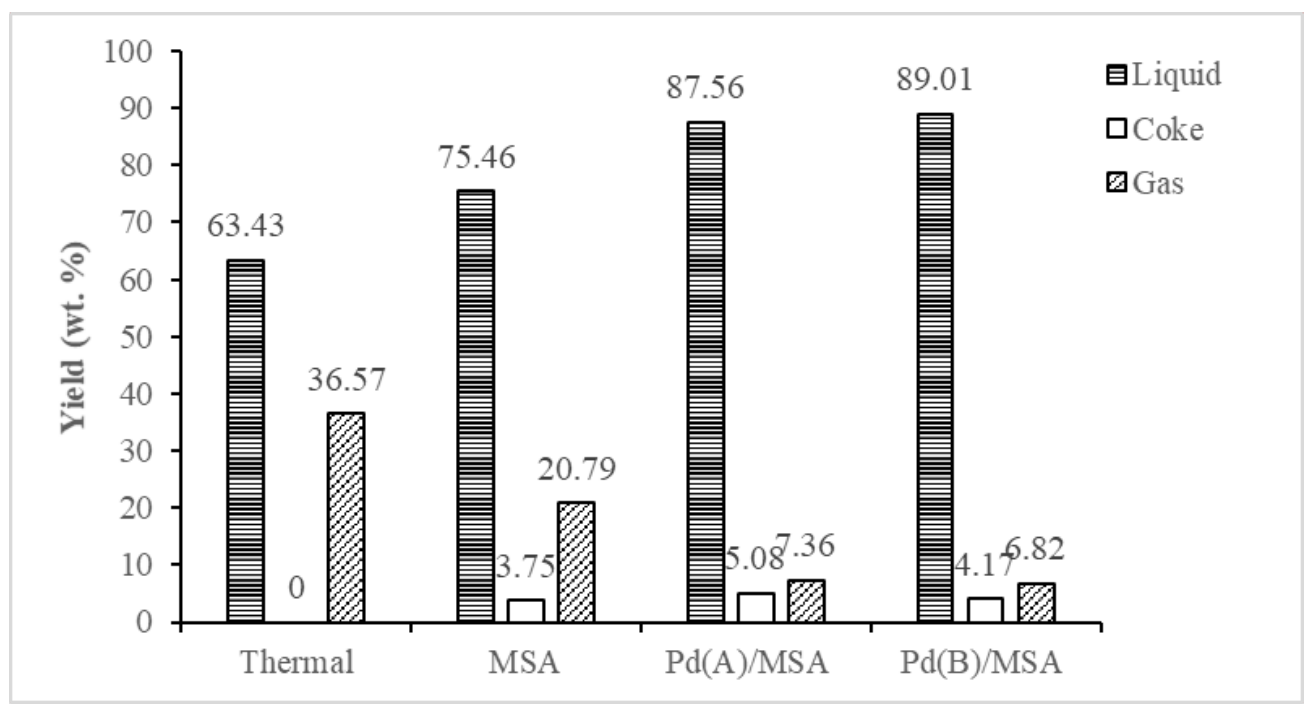

Fig.-5: Distribution of Hydrotreatment Products of Pyrolyzed $\alpha$-cellulose

The composition of liquid products obtained from the hydrotreatment process was analyzed using GCMS. Table-4 presents the results. The liquid products from the hydrotreatment process of pyrolyzed $\alpha-$ cellulose with catalysts and without using a catalyst (thermal) contain compounds in the form of acids, aldehydes, and ketones. Hydrotreatment of pyrolyzed $\alpha$-cellulose without using a catalyst produced 9octadecanoic acid compound as the main product. Different results obtained in the hydrotreatment process using catalysts. The hydrotreatment of pyrolyzed $\alpha$-cellulose using $\operatorname{Pd}(\mathrm{A}) / \mathrm{MSA}$ and $\mathrm{Pd}(\mathrm{B}) / \mathrm{MSA}$ catalyst 
RASĀYAN J. Chem.

Vol. 13 | No. 2 |1104 - 1111| April - June | 2020

produce acetic acid compounds as the main product. The complete catalyst activity test results are presented in Table-4.

Table-4: Selectivity of Liquid Product of Hydrotreatment of Pyrolyzed $\alpha$-cellulose

\begin{tabular}{c|c|c|c|c|c}
\hline \multirow{2}{*}{ Group } & Product & \multicolumn{4}{|c}{ Composition (wt. \%) } \\
\cline { 2 - 6 } & & Thermal & MSA & Pd(A)/MSA & Pd(B)/MSA \\
\hline \multirow{4}{*}{ Acid } & Acetic acid & - & 21.60 & 16.79 & 21.89 \\
& Propanoic acid & - & - & 6.58 & 8.11 \\
& Hexadecenoic acid & 12.29 & - & - & - \\
& 9,12-hexadecedinoic acid & 5.60 & - & - & - \\
\hline \multirow{2}{*}{ Ketones } & 9-octadecanoic & 13.45 & - & - & - \\
& 1-hydroxy-2-propanone & 5.89 & 17.19 & 14.78 & - \\
\hline \multirow{3}{*}{ Aldehyde } & acetone & - & 5.40 & - & 12.81 \\
& 2-furancarboxyldehyde & - & 9.54 & 15.26 & 10.61 \\
& Formaldehyde & - & - & - \\
& Acetaldehyde & - & 7.95 & - & - \\
\hline
\end{tabular}

\section{CONCLUSION}

MSA synthesized in this study had a specific BET surface area of $602.61 \mathrm{~m}^{2} / \mathrm{g}$, the total pore volume of $0.81 \mathrm{~cm}^{3} / \mathrm{g}$ and a pore diameter of $3.60 \mathrm{~nm}$ based on the BJH desorption method. The MSA acidity value increases after the impregnation of Pd metal. Hydrotreatment of pyrolyzed $\alpha$-cellulose produced the highest amount of liquid product using $\operatorname{Pd}(\mathrm{B}) / \mathrm{MSA}$ catalyst of $89.01 \mathrm{wt} . \%$ with the main product in the form of acetic acid compounds.

\section{ACKNOWLEDGMENT}

The authors thank the Ministry of Research Technology and Higher Education of Indonesia for financial support for this research under the PTUPT 2019 research fund at Universitas Gadjah Mada (Contract Number: 2744/UN1.DITLIT/DIT-LIT/LT/2019).

\section{REFERENCES}

1. S. Wang, G. Dai, H. Yang, and Z. Luo, Progress in Energy and Combustion Science, 62, 33(2017), DOI:10.1016/j.pecs.2017.05.004

2. W. Trisunaryanti, T. Triyono, R. Armunanto, L.P. Hastuti, D.D. Ristiana, and R.V. Ginting, Indonesian Journal of Chemistry., 18, 166(2018), DOI:10.22146/ijc.26491

3. F.H. Isikgor and C.R. Becer, Polymer Chemistry, 6, 4497(2015), DOI:10.1039/c5py00263j

4. A. V. Bridgwater, Biomass and Bioenergy, 38, 68(2012), DOI: 0.1016/j.biombioe.2011.01.048

5. M.A.F. Mazlan, Y. Uemura, N.B. Osman, and S. Yusup, Journal of Physics: Conference Series, 622, (2015), DOI:10.1088/1742-6596/622/1/012054

6. Z. Si, X. Zhang, C. Wang, L. Ma, and R. Dong, Catalysts, 7, 1(2017), DOI:10.3390/catal7060169

7. F. Regali, L.F. Liotta, A.M. Venezia, V. Montes, M. Boutonnet, and S. Järås, Catalysis Today, 223, 87(2014), DOI:10.1016/j.cattod.2013.08.028

8. M. Pongsendana, W. Trisunaryanti, F.W. Artanti, I.I. Falah, and Sutarno, Korean Journal of Chemical Engineering Eng., 34, 2591(2017), DOI:10.1007/s11814-017-0165-3

9. W. Trisunaryanti, I.I. Falah, and M.F. Marsuki, $15^{\text {th }}$ International Conference on Environmental Science and Technology, CEST2017 00741 (2017).

10. H. Kusumastuti, W. Trisunaryanti, I.I. Falah, and M.F. Marsuki, Rasayan Journal of Chemistry, 11(2), 522(2018), DOI:10.7324/RJC.2018.1122061

11. M.F. Marsuki, W. Trisunaryanti, I.I. Falah, and K. Wijaya, Oriental Journal of Chemistry, 34(2), 955(2018), DOI:10.13005/ojc/340245

12. R. Nuryanto, W. Trisunaryanti, I.I. Falah, and Triyono, IOP Conference Series: Materials Science and Engineering, 349, (2018), DOI:10.1088/1757-899X/349/1/012051

13. Y.S. Al-Zeghayer, P. Sunderland, W. Al-Masry, F. Al-Mubaddel, A.A. Ibrahim, B.K. Bhartiya, and 
RASĀYAN J. Chem.

Vol. 13 | No. 2 |1104 - 1111| April - June | 2020

B.Y. Jibril, Applied Catalysis A: General, 282, 163(2005), DOI:10.1016/j.apcata.2004.12.021

14. C. Cai, H. Wang, and J. Han, Applied Surface Science, 257, 9802(2011), DOI: 10.1016/j.apsusc.2011.06.025

15. J. Lee, S. Hwang, J.G. Seo, U.G. Hong, J.C. Jung, and I.K. Song, Journal of Industrial and Engineering Chemistry, 17, 310(2011), DOI:10.1016/j.jiec.2011.02.029

16. L.J. Olson, Oakland, and Calif, Chevron Research Company, (1975).

17. W. Trisunaryanti, P.S. Lisna, I. Kartini, Sutarno, I.I. Falah, and Triyono, Asian Journal of Chemistry, 28, 996(2016), DOI:10.14233/ajchem.2016.19561

18. M. Ahmad and S. Benjakul, Food Hydrocolloids, 25, 381(2011), DOI: 10.1016/j.foodhyd.2010.07.004

19. F.W. Artanti, W. Trisunaryanti, M. Pongsendana, Triyono, I.I. Falah, and M.F. Marsuki, Rasayan Journal of Chemistry, 11, 1433(2018), DOI:10.31788/RJC.2018.1143073

20. H. Kusumastuti, W. Trisunaryanti, I.I. Falah, and M.F. Marsuki, Rasayan Journal of Chemistry, 11, 522(2018), DOI:10.7324/RJC.2018.1122061

21. W. Trisunaryanti, I.I. Falah, D.R. Prihandini, and M.F. Marsuki, Rasayan Journal of Chemistry, 12, 1523(2019), DOI:10.31788/RJC.2019.1235297

22. S. Sinthusamran, S. Benjakul, and H. Kishimura, Food Chemistry, 152, 276(2014), DOI: 10.1016/j.foodchem.2013.11.109

23. J.H. Muyonga, C.G.B. Cole, and K.G. Duodu, Food Hydrocolloids, 18, 581(2004), DOI: 10.1016/j.foodhyd.2003.08.009

24. I. Gustian, Ghufira, and D. Oktiarni, Rasayan Journal of Chemistry, 10, 689(2017), DOI: 10.7324/RJC.2017.1031716

25. A.D. Prasiwi, W. Trisunaryanti, T. Triyono, I.I. Falah, D. Santi, and M.F. Marsuki, Indonesian Journal of Chemistry, 19, 575(2019), DOI:10.22146/ijc.34189

26. W. Trisunaryanti, T. Triyono, I.I. Falah, A.D. Siagian, and M.F. Marsuki, Indonesian Journal of Chemistry, 18, 441(2018), DOI:10.22146/ijc.31717

27. D.P. Wijaya, W. Trisunaryanti, Triyono, K. Dewi, and M.F. Marsuki, Oriental Journal of Chemistry, 34, 1847(2018), DOI:10.13005/ojc/3404019

28. W. Trisunaryanti, E. Suarsih, Triyono, and I.I. Falah, RSC Advances, 9, 1230(2019), DOI: $10.1039 / \mathrm{c} 8 \mathrm{ra} 09034 \mathrm{c}$

[RJC-5630/2019] 